\title{
The Brine Shrimp Artemia Survives in Diluted Water of Lake Bunyampaka, an Inland Saline Lake in Uganda
}

\author{
Martin Sserwadda ${ }^{1,2, *} \mathbb{D}$, Edmond Kagambe ${ }^{2}$ and Gilbert Van Stappen ${ }^{1}$ \\ 1 Laboratory of Aquaculture \& Artemia Reference Center, Ghent University, Coupure Links 653, \\ B-9000 Gent, Belgium; Gilbert.vanstappen@ugent.be \\ 2 Department of Agriculture and Environmental Sciences, Mountains of the Moon University, \\ Fort Portal 256, Uganda; Edmondkagambe@yahoo.com \\ * Correspondence: martin.sserwadda@ugent.be or martinsserwadda5@gmail.com; Tel.: +25-67-7236-2624
}

Received: 25 October 2017; Accepted: 13 December 2017; Published: 11 February 2018

\begin{abstract}
Ugandan aquaculture is in the process of development; however, it requires access to an affordable live food source, such as brine shrimp Artemia. This study fits within a broader feasibility study of domestic Artemia production in salt lakes. Since Uganda is a landlocked country, the only opportunity for live water food sources lies in the salt lakes in the west of the country. This study used saline water from one of these lakes, Lake Bunyampaka (salinity $72 \mathrm{mg} \mathrm{L}^{-1}$ ). Two Artemia strains, i.e., the Great Salt Lake strain, which is the dominant strain on the market, and the Vinh Chau strain, which is by far the most inoculated strain in the world, were assayed for their survival, growth, and reproduction in diluted Lake Bunyampaka water, using natural seawater as control. The organisms were fed live freshly cultured microalgae Tetraselmis suecica ad libitum. Our study revealed that the Vinh Chau strain performed especially well in Lake Bunyampaka water diluted to $50 \mathrm{~g} \mathrm{~L}^{-1}$. The data presented in this study generate the first useful information for the future inoculation of Artemia in Lake Bunyampaka in Uganda, and hence domestic Artemia production in the country; however, further larger-scale laboratory work, followed by field trials, is still needed.
\end{abstract}

Keywords: brine shrimp Artemia; salinity; ionic composition; Lake Bunyampaka; Uganda

\section{Introduction}

Land, labour, capital, and entrepreneurship are the four core factors of production, and apply to the aquaculture sector the world over, Uganda inclusive. During the last 10 years, aquaculture growth in Uganda has been tremendous, increasing from a production of about 600 tons in 1994 to about 100,000 tons in 2014 [1,2]. This increasing trend has been due to Uganda identifying and addressing the major constraints that have historically affected the fish farming industry, such as quality seed and fish feed. In this regard, the government has established several public fish fry centers, and encouraged private farmers to establish fish hatcheries to address the issue of fish seed. However, despite the increased efforts to boost farmed fish production, hatchery operators still face many problems in larviculture, with most hatcheries reporting a survival rate of below 25\% [3]. Most of these mortalities could be attributed to the lack of a suitable larval feed that both meets the nutritional requirements for fish and is affordable for the hatchery operators. At this stage of development, fish larvae require a feed that is nutritionally complete to supply all of the required nutrients in their right amounts, and that is small enough to go through the small mouth gape of the fish larvae. It's also known that fish larvae get digestive enzymes and hormonal precursors from the ingested food, which in turn boosts their immunity. Now, there is no single dry artificial diet that can completely substitute 
live feeds, so the feeding of live feeds to fish larvae generally still remains essential in commercial hatchery operations [4].

In nature, fish larvae do depend on several phytoplankton and zooplankton species for their nutritional requirements, but in marine larviculture, the brine shrimp Artemia sp. has proved to be very successful as a larval feed [5-8]. This crustacean is available in the form of cysts worldwide, and the larvae ("nauplii") hatching from those cysts are nutritionally adequate and small enough (400-450 $\mu \mathrm{m})$ for many small larval fish to ingest them [5]. Artemia can also be easily manipulated to meet fish larvae nutritional requirements through bioencapsulation [4,5]. In freshwater aquaculture, Artemia has been used to improve survival in the larviculture of freshwater prawn (Macrobrachium sp.), whitefish larvae (family Coregonidae), walleye larvae (Stizostedion vitreum), striped bass larvae (Morone saxatilis), African catfish (Clarias gariepinus), and African lungfish (Protopterus ethiopicus), amongst others [9-13]. The major drawback for Artemia use in freshwater fish culture has always been the short survival period of Artemia in freshwater, which is in the order of $30 \mathrm{~min}$ to $60 \mathrm{~min}$ [14]. Therefore, they are not continuously available to the larval fish, as is the case in marine larviculture systems, and ideally they should be fed intermittently every $2 \mathrm{~h}$ to $3 \mathrm{~h}$ [11].

Artemia can survive in hypersaline environments where none of its predators are capable of surviving [15]. These environments suitable for Artemia do vary considerably in terms of ionic composition, climatic conditions, seasonality, productivity, altitude, and other characteristics [16-19]. Artemia has been shown $[20,21]$ to inhabit chloride, sulphate or carbonate waters, and/or combinations of two or even three major anions [18]. There are seven bisexual species and numerous parthenogenetic populations [22]. Of these species, Artemia franciscana Kellogg 1906 is by far the most important one for aquaculture use, and it is the species that has been introduced in salt-works for integrated Artemia-salt production, especially in areas where there is no natural occurrence of Artemia [18].

Currently, hatchery operators in Uganda are using both live and dry feeds in African catfish larval feeding and weaning regimes, but with low survival rates [23]. Artemia is one of the live feeds used in the country; however, farmers have cited major problems, such as high prices, low quality, and the irregular availability of the product [23]. Local Artemia production in Uganda is expected to enhance aquaculture production, especially for African catfish production, as it will increase the availability of cysts and/or biomass for use in hatchery operations. This local production would reduce purchasing costs of Artemia cysts, and hence increase profits for the hatchery operators. If combined with local salt production, a commercially active Artemia production sector would increase incomes for local salt farmers, who would be able to harvest both salt and Artemia cysts from their salt ponds, and also reduce unemployment.

Uganda, a landlocked country, is naturally endowed with many saline crater lakes in the Rwenzori region in the west of the country, although there is no natural occurrence of Artemia in these saline environments [24]. In several of these crater lakes, the local rural communities produce artisanal salt. Lake Bunyampaka is one of the saline lakes where salt is mined for use in the livestock sector, and could provide a suitable environment for Artemia culture as an alternative source of livelihood to the salt miners. This study reports on laboratory tests, and aims to assess the suitability of Lake Bunyampaka saline water to culture Artemia, as a first phase of research before field culture tests can be considered.

Artemia performance in the water of Lake Bunyampaka was assessed (1) by investigating the survival of two strains of $A$. franciscana, i.e., Great Salt Lake (GSL), from the United States, and Vinh Chau (VC) from Vietnam; and (2) by assessing the reproductive performance of the Vinh Chau strain, as it had performed better than the GSL strain in the first experiment.

\section{Materials and Methods}

\subsection{Saline Water Used}

Lake Bunyampaka $\left(00^{\circ} 2^{\prime} 25.62^{\prime \prime} \mathrm{S}, 30^{\circ} 7^{\prime} 46.53^{\prime \prime} \mathrm{E}\right)$, is one of the saline crater lakes situated in Queen Elizabeth National Park in western Uganda (Figure 1). It is a relatively shallow lake about 
0.3-0.5 m deep [25]. It is an alkaline lake with $\mathrm{pH} 9.5$ [25]. Its salinity changes depending on the season; field sampling with a hand-held refractometer (WZ-211, Beijing Smartech Corporation, Beijing, China) over two years measured salinity as high as $88.1 \pm 14.6 \mathrm{mg} \mathrm{L}^{-1}$ in the dry season, and $72.4 \pm 11.2 \mathrm{mg} \mathrm{L}^{-1}$ in the rainy season [25]. Water was collected from a channel in the middle of Lake Bunyampaka during the rainy season. Surface water was collected in a $5 \mathrm{~L}$ jerry can and transported by air to Ghent University, Belgium. Upon arrival, the water was kept at $4{ }^{\circ} \mathrm{C}$ until the culture tests. These were done at the Laboratory of Aquaculture and Artemia Reference Centre (ARC), Ghent University, Belgium. Table 1 summarizes the results of water analysis, as conducted at the Laboratory of Environmental Toxicology and Aquatic Ecology, Ghent University, Belgium, using an iCap 7200 dual view inductively coupled plasma-optical emission spectrometer (ICP-OES, Thermo Scientific, Gent, Belgium) for $\mathrm{Na}^{+}, \mathrm{K}^{+}, \mathrm{Ca}^{2+}$, and $\mathrm{Mg}^{2+}$, and test kits for the other ions. The salinity of the water was $72 \mathrm{~g} \mathrm{~L}^{-1}$ when measured with a hand-held refractometer, which was model ORD/ATC WZ201/211.

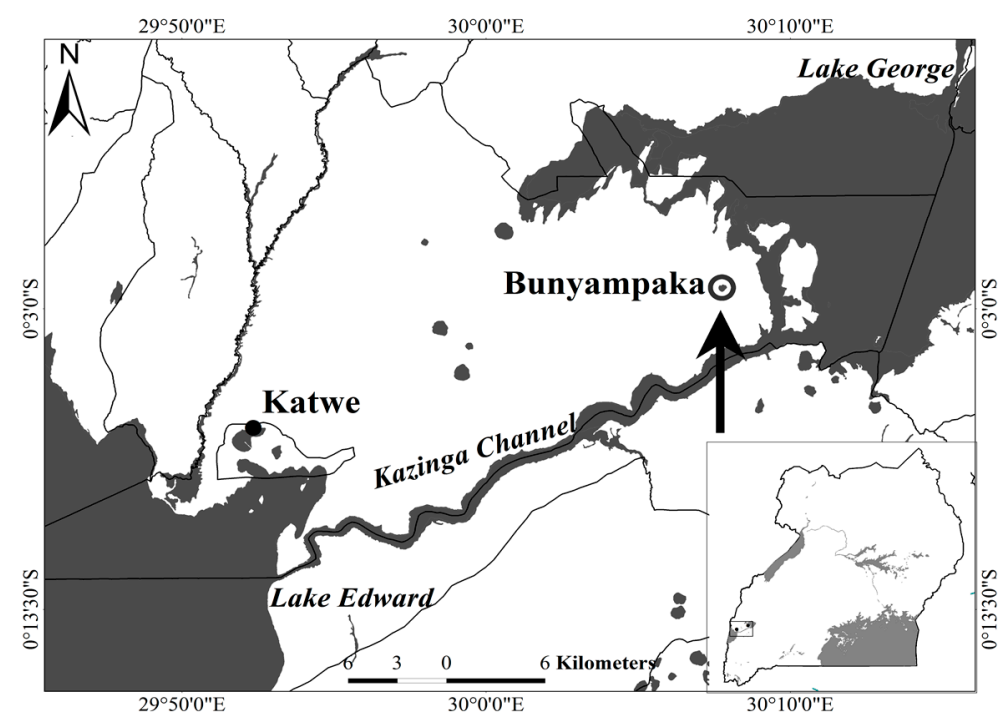

Figure 1. Detail map showing Lake Bunyampaka (left; see arrow) and its location in Uganda (inset bottom right).

Table 1. Water analysis results for the Lake Bunyampaka sample used for Artemia culture tests. ICP-OES: inductively coupled plasma-optical emission spectrometer.

\begin{tabular}{ccc}
\hline Parameter & Concentration & Method \\
\hline Sodium $\left(\mathrm{Na}^{+}\right)$ & $31,000 \mathrm{mg} \mathrm{L}^{-1}$ & ICP-OES \\
Potassium $\left(\mathrm{K}^{+}\right)$ & $115 \mathrm{mg} \mathrm{L}^{-1}$ & ICP-OES \\
Calcium $\left(\mathrm{Ca}^{2+}\right)$ & $1900 \mathrm{mg} \mathrm{L}^{-1}$ & ICP-OES \\
Magnesium $\left(\mathrm{Mg}^{2+}\right)$ & $80 \mathrm{mg} \mathrm{L}^{-1}$ & ICP-OES \\
Ammonium $\left(\mathrm{NH}_{4}^{+}-\mathrm{N}\right)$ & $12 \mathrm{mg} \mathrm{L}^{-1} \mathrm{~N}$ & Merck test kit: 114,752 \\
Nitrite $\left(\mathrm{NO}_{2}{ }^{-}-\mathrm{N}\right)$ & $0.13 \mathrm{mg} \mathrm{L}^{-1} \mathrm{~N}$ & Merck test kit: 114,776 \\
Nitrate $\left(\mathrm{NO}_{3}{ }^{-}-\mathrm{N}\right)$ & $1.2 \mathrm{mg} \mathrm{L}^{-1} \mathrm{~N}$ & Merck test kit: 114,773 \\
Phosphorus $\left(\mathrm{PO}_{4}{ }^{3-}-\mathrm{P}\right)$ & $32 \mathrm{mg} \mathrm{L}^{-1} \mathrm{P}$ & Merck test kit: 114,848 \\
Chloride $\left(\mathrm{Cl}^{-}\right)$ & $35,700 \mathrm{mg} \mathrm{L}^{-1} \mathrm{Cl}^{-}$ & Merck test kit: 114,897 \\
Sulphate $\left(\mathrm{SO}_{4}{ }^{2-}\right)$ & $7500 \mathrm{mg} \mathrm{L}^{-1} \mathrm{SO}_{4}{ }^{2-}$ & Merck-test kit: 114,548 \\
\hline
\end{tabular}

Note: Culture conditions and Artemia strains used; Merck test kit: HS Code 382200 00; Merck, Darmstadt, Germany.

The Lake Bunyampaka water was diluted to different salinities, i.e., $30 \mathrm{~g} \mathrm{~L}^{-1}$ and $50 \mathrm{~g} \mathrm{~L}^{-1}$ using demineralized water, after having filtered it through a GE-Whatman Cellulose Filter Grade 4: 20-25 $\mu \mathrm{m}$ filter, and used thereafter for culture tests. All of the tests were conducted in a room acclimated at $28 \pm 1{ }^{\circ} \mathrm{C}$, which is the standard temperature for Artemia laboratory culture, as conducted at the 
Laboratory of Aquaculture and Artemia Reference Center (15), and is also close to the year-round water temperature of $30.3 \pm 1.5^{\circ} \mathrm{C}$ of the lake (25). Artemia were fed with live freshly cultured Tetraselmis suecica Butcher (1959) strain 66/4 ad libitum. An inoculum of this strain had been obtained from the Culture Collection of Algae and Protozoa (CCAP), UK, and the algae had been cultured following a standard protocol [26]. The VC Artemia strain was chosen since it is the most inoculated strain in solar salt-works in most parts of the world for local Artemia production, while the GSL strain was chosen because it is the dominant strain on the market.

\subsection{Experiment 1: Survival Experiment with Both GSL and VC Strains at $30 \mathrm{~g} \mathrm{~L}^{-1}$}

In a preparatory experiment, we wanted to find out if the two Artemia strains would survive in the water of Lake Bunyampaka. Since the ionic composition of the lake is not identical to the environment of origin of the GSL and VC strains, diluted lake water was used. Artemia hatching was achieved by use of natural sea water in a falcon tube filled up to $35 \mathrm{~mL}$, to which $70 \mathrm{mg}$ of cysts was added, and placed on a rotor at four cycles $\min ^{-1}$ for $24 \mathrm{~h}$ under constant illumination $\left( \pm 41 \mu \mathrm{E} \mathrm{m} \mathrm{m}^{-2} \mathrm{~s}^{-1}\right)$ using fluorescent lamps. Upon hatching, instar I nauplii were transferred into cylindrical shaped vials (45 mL) (50 nauplii each) filled with Lake Bunyampaka saline water at $30 \mathrm{~g} \mathrm{~L}^{-1}$ salinity, and were fed with live freshly cultured Tetraselmis suecica algae ad libitum, which was the feed used throughout the tests. Natural sea water at $35 \mathrm{~g} \mathrm{~L}^{-1}$ was used as a control medium. Each treatment had three replicates. No artificial aeration was used but to ensure sufficient oxygen levels; water renewal was done upon survival determination on days 4,8 , and 12 . One third of the culture water was replaced. Final survival was determined at the end of the experiment on day 15 . When riding couples were seen, it was noted as the time in days when sexual maturity was attained at the earliest in those animals.

\subsection{Experiment 2: Survival and Growth Experiment with the VC Strain at $30 \mathrm{~g} \mathrm{~L} \mathrm{~L}^{-1}$}

After the first culture of both strains (Experiment 1), VC was seen to be performing better in terms of survival than GSL when cultured in diluted Lake Bunyampaka saline water. We therefore designed a second experiment to investigate the survival and growth of the VC strain in diluted Lake Bunyampaka water at $30 \mathrm{~g} \mathrm{~L}^{-1}$ salinity. Hatching was achieved by using filtered diluted Lake Bunyampaka water at $30 \mathrm{~g} \mathrm{~L}^{-1}$. Fifty instar I nauplii were then transferred to $100 \mathrm{~mL}$ Scott glass bottles, which were each filled with $50 \mathrm{~mL}$ of water, in three replicates. Natural sea water at $35 \mathrm{~g} \mathrm{~L}^{-1}$ was used as a control medium. Survival determination was done more frequently and over a longer period than in Experiment 1, i.e., on days 4, 7, 11, 14, 18, and 20. Water renewal was done upon survival determination. To obtain more detailed information on Artemia performance, length measurement was also done in Experiment 2, i.e., on days 7 and 20, measuring 15 animals/replicate. To measure the length, a light microscope NIKON SMZ1270i equipped with software NIS-elements D version 4.3 for automatic length measurements was used to measure the length of brine shrimp from the anterior of the head to the end of the telson. This experiment provided the animals used for the reproductive performance test (Experiment 3).

\subsection{Experiment 3: Reproduction Experiment with the VC Strain at $30 \mathrm{~g} \mathrm{~L}^{-1}$ and $50 \mathrm{~g} \mathrm{~L}^{-1}$}

At reproductive maturity, the surviving individuals of Experiment 2 were transferred to falcon tubes containing $30 \mathrm{~mL}$ of saline water at $30 \mathrm{~g} \mathrm{~L}^{-1}$ salinity. For the Experiment 2 control, couples were seen on day 17, and 10 couples were taken out of each of the three Scott glass bottles of the control, and each was transferred to a falcon tube, giving a total of 30 couples. For the treatment with diluted Lake Bunyampaka water of $30 \mathrm{~g} \mathrm{~L}^{-1}$ salinity in Experiment 2, couples were first seen on day 21, and again 10 couples were picked from each of the three Scott bottles (equaling 30 couples in total) to observe reproduction at the same salinity. As more couples were seen in Experiment 2 (30 $\mathrm{g} \mathrm{L}^{-1}$ salinity) as of day 25 onwards, another 30 couples were taken subsequently to observe reproduction at $50 \mathrm{~g} \mathrm{~L}^{-1}$. Every day, the falcon tubes were checked for survival and for the production of offspring (cysts or nauplii), based on which mean values of reproductive parameters were calculated 
(age at first offspring production; brood size; inter-brood interval; number of offspring/female/day; total offspring production; percentage offspring produced as cysts). If a male died, it was replaced by another male from the stock culture; if a female died, it was just recorded as mortality.

The reproduction test for all of the couples was terminated at the age of 50 days, and as all animals originated from one single batch of hatched animals that were first used in Experiment 2, this implies that the reproduction period observed for the $50 \mathrm{~g} \mathrm{~L}^{-1}$ couples was a few days shorter than for the $30 \mathrm{~g} \mathrm{~L}^{-1}$ and the control couples.

\subsection{Statistical Analysis}

Survival data were analyzed for statistical differences by subjecting the data to logistic regression analysis using GenStat 16 (VSN International, Hemel Hempstead, UK). Significance level was set to the lowest significant difference of the means and was manually adjusted. The overall significant difference between the proportion of survival animals at the same time point, as expressed graphically, was determined by chi square $\left(x^{2}<0.001\right)$.

Data for the reproductive performance of the VC strain in different culture media in Experiment 3 (reproduction test) did not obey the rules of normality and equal variances, and were analyzed by an independent samples Kruskal-Wallis test to detect the effect of the treatment, followed by the post hoc test (Wilcoxon rank sum test) to show pairwise comparisons.

\section{Results}

\subsection{Experiment 1: Survival Experiment with Both GSL and VC Strains at $30 \mathrm{~g} \mathrm{~L}^{-1}$}

As shown in Figure 2A,B, both strains of Artemia survived in Lake Bunyampaka saline water when diluted to $30 \mathrm{~g} \mathrm{~L}^{-1}$. The survival of the GSL strain was significantly lower than the control for GSL (CGSL) from day 4 up to day 15 (Figure 2A). The mean differences of the proportion of survived animals for CGSL versus GSL were $0,0.1266,0.4933,0.4934$, and 0.4734 for the time points of day 0,4 , 8,12 , and 15 of culture, respectively. For the VC strain, there was a gradual decline in survival in the Lake Bunyampaka water over the entire culture period, but the survival of VC was significantly higher than that of the control for VC (CVC) (Figure 2B). The mean differences of the proportion of survived animals for CVC versus VC were $0,0.1333,0.1333,0.1$, and 0.1667 for the time points of day $0,4,8,12$, and 15 of culture, respectively. Comparison between the two strains showed that from day 4 onwards up to day 15, VC exhibited a significantly higher survival than GSL (Figure 3). The mean differences of the proportion of survived animals for GSL versus VC were $0,0.1066,0.5933,0.56$, and 0.5067 for the time points of day $0,4,8,12$, and 15 of culture, respectively.



Figure 2. Cont. 


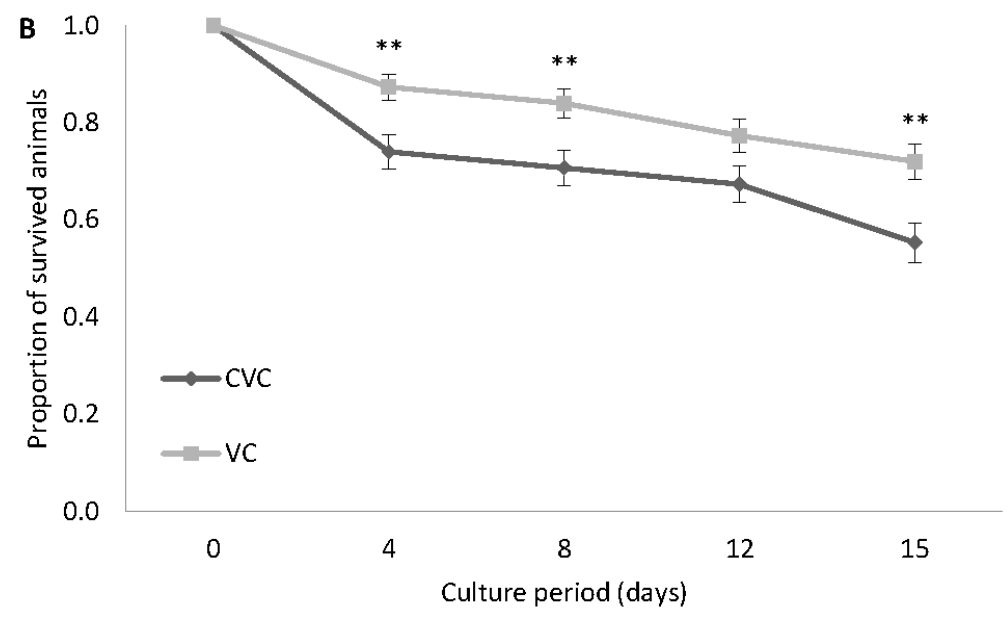

Figure 2. Experiment 1. Proportion of surviving Artemia cultured in Lake Bunyampaka saline water at $30 \mathrm{~g} \mathrm{~L}^{-1}$ for 15 days; GSL (A) and VC (B). Values are presented as means \pm SE. $(n=3),{ }^{*} p<0.05$, ${ }^{* *} p<0.01,{ }^{* * *} p<0.001,{ }^{* * * *} p<0.0001,{ }^{* * * * *} p<0.00001,{ }^{* * * * * *} p<0.000001$ vs. the corresponding control group. GSL: Great Salt Lake, CGSL: Control for Great Salt Lake, VC: Vinh Chau, CVC: Control for Vinh Chau.

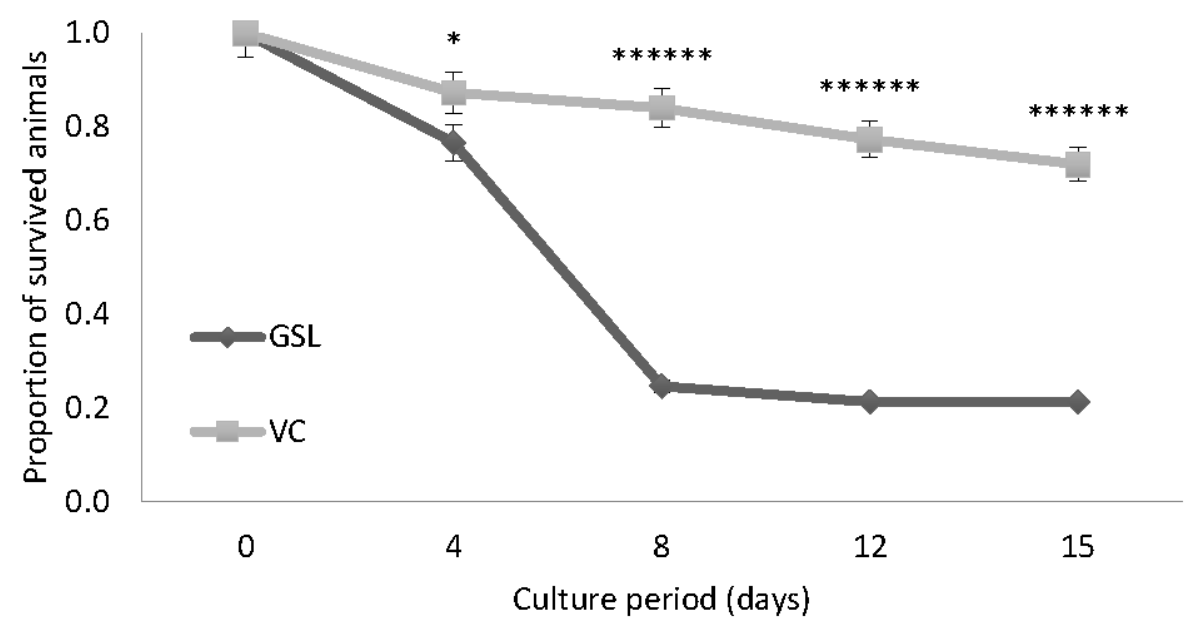

Figure 3. Experiment 1. Proportion of surviving Artemia cultured in Lake Bunyampaka saline water at $30 \mathrm{~g} \mathrm{~L}^{-1}$ for 15 days; GSL (A) and VC (B). Values are presented as means \pm SE. $(n=3),{ }^{*} p<0.05$, ${ }^{* *} p<0.01,{ }^{* * *} p<0.001,{ }^{* * * *} p<0.0001,{ }^{* * * * *} p<0.00001,{ }^{* * * * * *} p<0.000001$ vs. the corresponding treatment group. GSL: Great Salt Lake, CGSL: Control for Great Salt Lake, VC: Vinh Chau, CVC: Control for Vinh Chau.

\subsection{Experiment 2: Survival and Growth Experiment with the VC Strain at $30 \mathrm{~g} \mathrm{~L}^{-1}$}

From Experiment 1, as seen in Figure 3, VC seemed to be the most promising strain. Therefore, a second experiment was performed with the VC strain for an extended culture period, whose aim was also to obtain sufficient animals for the reproduction test (Experiment 3).

The VC strain was still able to survive in Lake Bunyampaka saline water at salinity $30 \mathrm{~g} \mathrm{~L}^{-1}$ for a longer culture period of 20 days, as shown in Figure 3. The proportion of Artemia nauplii surviving in diluted Lake Bunyampaka water was high for the first seven days, followed by a decline until day 14, and levelling off towards the end of the culture period culture (Figure 4). The VC strain attained sexual maturity, and couples in riding position were seen on day 21 in Lake Bunyampaka water, while in the control, this was on day 17. 


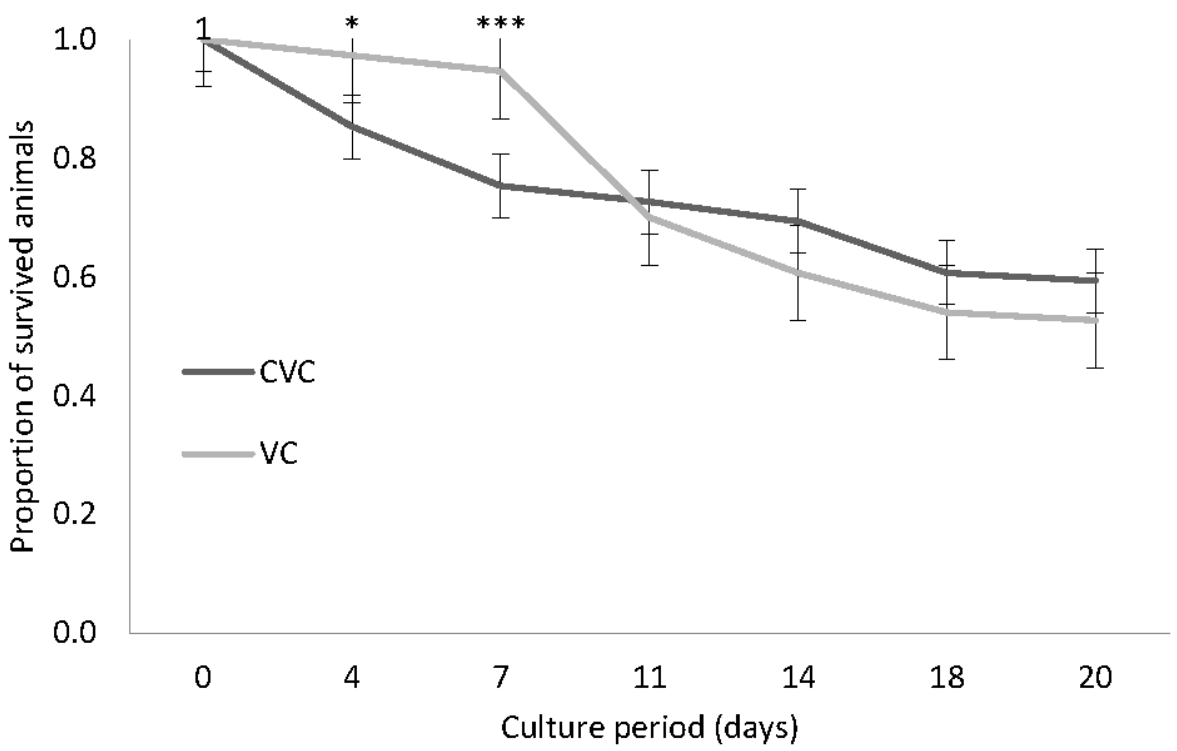

Figure 4. Experiment 2. Proportion of surviving Artemia cultured in Lake Bunyampaka saline water at $30 \mathrm{~g} \mathrm{~L}^{-1}$ for 20 days. Values are presented as means \pm SE. $(n=3),{ }^{*} p<0.05,{ }^{* *} p<0.01,{ }^{* * *} p<0.001$, ${ }^{* * * *} p<0.0001,{ }^{* * * * *} p<0.00001,{ }^{* * * * * *} p<0.000001$ vs. the corresponding control group. VC: Vinh Chau, CVC: Control for Vinh Chau.

\subsection{Experiment 3: Reproduction Experiment with the VC Strain at $30 \mathrm{~g} \mathrm{~L}^{-1}$ and $50 \mathrm{~g} \mathrm{~L}^{-1}$}

The VC performed well as it reproduced in all three culture media. There were significant differences between its performance at $50 \mathrm{~g} \mathrm{~L}^{-1}$ and the performance of the control for the parameters of age at first offspring, number of offspring per female per day, and total offspring production (Table 2). Couples at $50 \mathrm{~g} \mathrm{~L}^{-1}$ salinity took a significantly longer time to produce their first offspring as compared with the control. Also, the couples at $50 \mathrm{~g} \mathrm{~L}^{-1}$ salinity had significantly lower offspring per female per day than the control, but not significantly different from those at $30 \mathrm{~g} \mathrm{~L}^{-1}$. Total offspring production was highest in Artemia cultured in natural seawater followed by that in $30 \mathrm{~g} \mathrm{~L}^{-1}$, and lowest in Artemia cultured at $50 \mathrm{~g} \mathrm{~L}^{-1}$ Lake Bunyampaka water. The brood size was smallest in females at $50 \mathrm{~g} \mathrm{~L}^{-1}$ salinity, followed by the control, and the $30 \mathrm{~g} \mathrm{~L}^{-1}$ salinity, although the three values were not statistically significant. The inter-brood interval was slightly longer in couples at $50 \mathrm{~g} \mathrm{~L}^{-1}$ salinity than at $30 \mathrm{~g} \mathrm{~L}^{-1}$ and the control, but this difference was not statistically significant. The percentage of encysted offspring varied among the culture environments from a minimum of $16 \%$ (50 g L ${ }^{-1}$ salinity Lake Bunyampaka) to a maximum of $21 \%\left(30 \mathrm{~g} \mathrm{~L}^{-1}\right.$ salinity Lake Bunyampaka).

Table 2. Reproductive parameters determined for VC Artemia cultured in Lake Bunyampaka water of different salinities and in a control medium over 50 days of observation.

\begin{tabular}{cccc}
\hline Characteristics & \multicolumn{2}{c}{ Lake Bunyampaka Water } & Control \\
\hline Salinity & $30 \mathrm{~g} \mathrm{~L}^{-1}$ & $50 \mathrm{~g} \mathrm{~L}^{-1}$ & $35 \mathrm{~g} \mathrm{~L}^{-1}$ \\
Age at first offspring & $28 \pm 0.4^{\mathrm{ab}}$ & $35.5 \pm 1.6^{\mathrm{a}}$ & $23.7 \pm 1.1^{\mathrm{b}}$ \\
Brood size & $4.2 \pm 0.6^{\mathrm{a}}$ & $2.9 \pm 0.9^{\mathrm{a}}$ & $4.5 \pm 0.5^{\mathrm{a}}$ \\
Inter-brood interval (days) & $3 \pm 0.4^{\mathrm{a}}$ & $3.5 \pm 0.3^{\mathrm{a}}$ & $3.4 \pm 0.3^{\mathrm{a}}$ \\
Number of offspring/female/day & $18 \pm 1^{\mathrm{ab}}$ & $10 \pm 4^{\mathrm{b}}$ & $28 \pm 4^{\mathrm{a}}$ \\
Total offspring production & $4574 \pm 243^{\mathrm{ab}}$ & $2650 \pm 871^{\mathrm{b}}$ & $6952 \pm 555^{\mathrm{a}}$ \\
Percentage offspring produced as cysts & $21 \pm 6.8^{\mathrm{a}}$ & $16 \pm 5.1^{\mathrm{a}}$ & $20.6 \pm 10.3^{\mathrm{a}}$ \\
\hline
\end{tabular}

Note: ${ }^{\text {ab }}$ Means within the same row with the same superscript are not significantly different (Kruskal-Wallis, $p<0.05$ ). The values represent the mean \pm SD of 30 couples. 


\section{Discussion}

The impact of environmental stress on an organism depends mainly on the frequency and magnitude of the disturbance, and the organism's ability to have compensatory growth [27]. Sublethal stress may lead to reduced survival and reproductive potential in the individual, and consequently a change in population structure, even though compensatory mechanisms may allow the organism to survive. In our experiments, which fit within a broader study to assess the feasibility of Artemia culture in salt lakes in western Uganda, we observed sublethal and lethal salinity effects in Artemia. In prior tests, there was total mortality in Artemia cultured in undiluted Lake Bunyampaka water (results not shown).

For this reason, this study evaluated the performance in terms of survival, growth and reproduction of Artemia in diluted water from Lake Bunyampaka. This also allowed us to run more tests with the $5 \mathrm{~L}$ stock of original lake water.

In its non-diluted form, the salinity of the Lake Bunyampaka water used for our tests was $72 \mathrm{~g} \mathrm{~L}^{-1}$. High salinity is the commonest feature of all of the Artemia biotopes, and is the predominant abiotic factor determining the presence of Artemia and limiting its geographical distribution [28]. Artemia is known to have an efficient osmoregulatory system that enables it to maintain osmotic homeostasis, even at elevated salinities [28]. However, it does this at an increased energy cost, which may affect other metabolic and physiological functions such as growth and reproduction $[27,28]$. The lower fecundity observed in Experiment 3 at the higher salinity $\left(50 \mathrm{~g} \mathrm{~L}^{-1}\right)$ may be the result of such increased energy costs for osmotic homeostasis. Couples at $50 \mathrm{~g} \mathrm{~L}^{-1}$ salinity took a relatively longer time to produce their first offspring; they also had less offspring/female/day, and consequently lower values for total offspring produced (Table 2).

Moreover, osmotic pressure differs as a function of the salt composition [28], and thus the cost of osmoregulation may also differ in media of the same salinity, but with different ionic environments. Artemia has been documented to withstand environments in which the ratio of major anions and cations may be totally different from that in seawater [29], even environments where this ratio reaches extremely high or low values in comparison to natural seawater. The Lake Bunyampaka saline water that was used showed different concentrations and proportions of ions as compared to seawater. The $\mathrm{Na}^{+} / \mathrm{K}^{+}$molar ratio was very high (450) compared with the range (8-173) that has been documented in other Artemia habitats [28,30,31]. On the contrary, the $\mathrm{Cl}^{-} / \mathrm{SO}_{4}{ }^{2-}$ molar ratio was very low (0.078) compared with the established range (0.5-90) for Artemia biotopes [28,30,31]. This could explain the lower performance that was generally observed for both strains in Lake Bunyampaka water (especially at $50 \mathrm{~g} \mathrm{~L}^{-1}$ ) than in natural seawater (the control), which is identical to the natural environment of Artemia from Vinh Chau (living in coastal salt-works) and the Great Salt Lake (a seawater type, so-called thalassohaline, lake [31]). If the ionic composition of the new environment is too different from the strain's native habitat, it may be prohibitive as a culture environment to produce a particular strain of Artemia [31].

The better performance of the Vinh Chau strain in Experiment 1, as compared with the Great Salt Lake strain, may be attributed to the higher ability of the former to adapt to adverse environments. This is consistent with earlier findings that the Vinh Chau strain displays a distinctive profile for fitness-related attributes at increased temperatures because of thermal adaptation [32]. Further support is provided by the observation of the significantly higher survival of the Vinh Chau strain grown at $30{ }^{\circ} \mathrm{C}$ and $34{ }^{\circ} \mathrm{C}$ compared with San Francisco Bay A. franciscana, which originates from a more temperature climate [6]. It has been documented that the Vinh Chau strain is better adapted to stress conditions than other Artemia strains [33-35], and our study demonstrates that this could also apply to ionic stress.

This is the first evidence of Artemia culture in a Ugandan saline water environment, and demonstrates that the controlled culture of Artemia in diluted saline water from Lake Bunyampaka is biologically feasible. However, there still remains a need to undertake laboratory culture of Artemia with Lake Bunyampaka saline water at a larger scale (in the order of e.g., $100 \mathrm{~L}$ ) before field cultures 
in ponds by the lakeside can be considered. Moreover, for practical field application, it should be studied to what extent culture success can be obtained when using non-diluted water or water less diluted than in our experiments. There is also need to carry out systematic research on the primary production of Lake Bunyampaka as food for Artemia, and its seasonal fluctuations, in order to find out if the phytoplankton species composition and abundance may sustain relatively dense Artemia populations, as generally maintained in man-managed Artemia pond production. In view of the seasonal temperature fluctuations in the lake, the effect of temperature on the performance of Artemia should also be investigated using this saline water. However, our study may be the first to turn the local production of the brine shrimp Artemia, an essential commodity for the development of aquaculture, into a reality in Uganda.

Acknowledgments: Financial support for this work was provided through VLIR-UOS, programme ZIUS, 2013-2024, AP027, under the Institutional Cooperation with Mountains of the Moon University (MMU) Uganda Programme. Christ Mahieu (UGent, Belgium) is gratefully acknowledged for his continuous help in the laboratory work. We thank Rose Basiita and Richard Ddungu (NARO, Uganda) for reading through an earlier version of this manuscript.

Author Contributions: Martin Sserwadda, Edmond Kagambe and Gilbert Van Stappen conceived and designed the experiments; Martin Sserwadda performed the experiments; Martin Sserwadda and Gilbert Van Stappen analyzed the data; Martin Sserwadda wrote the paper.

Conflicts of Interest: The authors declare no conflict of interest.

\section{References}

1. Rutaisire, J.; Charo-Karisa, H.; Shoko, A.P.; Nyandat, B. Aquaculture for increased fish production in East Africa. Afr. J. Trop. Hydrobiol. Fish. 2009, 12, 74-79. [CrossRef]

2. Ministry of Agriculture, Animal Industry and Fisheries (MAAIF). Agricultural Sector Development and Strategic Plan 2012/11-2014/15; MAAIF: Entebbe, Uganda, 2010.

3. Walakira, J.; (National Fisheries Resources Research Institute, Jinja, Uganda). Personal communication, 2016.

4. Sarker, S.D.; Hanaee, J.; Agh, N.; Hanaee, M.; Dalazar, A. Studies on the enrichment of Artemia urmiana cysts for improving fish food value. J. Dairy Sci. 2005, 120, 107-112.

5. Van Stappen, G. Artemia. In Manual on the Production and Use of Live Food for Aquaculture; Lavens, P., Patrick Sorgeloos, P., Eds.; Food and Agriculture Organization (FAO): Rome, Italy, 1996; ISBN 9251039348.

6. Hoa, N.V. Seasonal Farming of the Brine Shrimp Artemia Franciscana in Artisanal Salt Ponds in Vietnam: Effects of Temperature and Salinity. Ph.D. Thesis, Ghent University, Ghent, Belgium, 2002.

7. Sorgeloos, P.; Hoa, D.N.; Wouters, R.; Wille, M.; Thanh, V.; Dong, T.K. A fresh-food maturation diet with an adequate HUFA composition for broodstock nutrition studies in black tiger shrimp Penaeus monodon (Fabricius, 1798). Aquaculture 2009, 297, 116-121.

8. Toi, H.T.; Boeckx, P.; Sorgeloos, P.; Bossier, P.; Van Stappen, G. Bacteria contribute to Artemia nutrition in algae-limited conditions: A laboratory study. Aquaculture 2013, 388, 1-7. [CrossRef]

9. Flüchter, J. Review of the present knowledge of rearing whitefish (Coregonidae) larvae. Aquaculture 1980, 19, 191-208. [CrossRef]

10. Kräeuter, J.N.; Woods, C., III. Culture of striped bass and its hybrids: First feeding to six months. In Hybrid Striped Bass Culture: Status and Perspective; UNC Sea Grant Publication UNCSG-87-03; North Carolina State University: Raleigh, NC, USA, 1987; pp. 23-32.

11. Bengtson, D.A.; Léger, P.; Sorgeloos, P. Use of Artemia as a food source for aquaculture. J. Artemia Biol. 1991, 11, 255-285.

12. Guthrie, K.M.; Rust, M.B.; Langdon, C.J.; Barrows, F.T. Acceptability of various microparticulate diets to first-feeding walleye Stizostedion vitreum larvae. Aquac. Nutr. 2000, 6, 153-158. [CrossRef]

13. Walakira, J.K.; Molnar, J.J.; Phelps, R.; Terhune, J. Culturing the African lungfish in Uganda: Effects of exogenous fish feed on growth performance in tanks. UJAS 2014, 15, 137-155.

14. Soundarapanian, P.; Saravanakumar, G. Effect of different salinities on the survival and growth of Artemia Spp. Curr. Res. J. Biol. Sci. 2009, 1, 20-22.

15. Lavens, P.; Sorgeloos, P. Manual on the Production and Use of Live Food for Aquaculture; Food and Agriculture Organization (FAO): Rome, Italy, 1996; ISBN 9251039348. 
16. Vanhaecke, P.; Tackaert, W.; Sorgeloos, P. The biogeography of Artemia: An updated review. J. Artemia Res. Appl. 1987, 1, 129-155.

17. Xin, N.; Sun, J.; Zhang, B.; Triantaphyllidis, G.V.; Van Stappen, G.; Sorgeloos, P. International study on Artemia. LI. New survey of Artemia resources in the People's Republic of China. Int. J. Salt Lake Res. 1994, 3, 105-112. [CrossRef]

18. Triantaphyllidis, V.G.; Abatzopoulos, J.T.; Sorgeloos, P. Review of the biogeography of the genus Artemia (Crustacea, Anostraca). J. Biogeogr. 1998, 25, 213-226. [CrossRef]

19. Browne, R.A.; Wanigasekera, G. Combined effects of salinity and temperature on survival and reproduction of five species of Artemia. J. Exp. Mar. Biol. Ecol. 2000, 244, 29-44. [CrossRef]

20. Bowen, S.T.; Fogarino, E.A.; Hitchner, K.N.; Dana, G.L.; Chow, V.H.S.; Buoncristiani, M.R.; Carl, J.R. Ecological isolation in Artemia: Population differences in tolerance of anion concentrations. J. Crustac. Biol. 1985, 5, 106-129. [CrossRef]

21. Bowen, S.T.; Buoncristiani, M.R.; Carl, J.R. Artemia habitats: Ion concentrations tolerated by one superspecies. Hydrobiologia 1988, 158, 201-214. [CrossRef]

22. Asem, A.; Rastegar-Pouyani, N.; De Los Ríos-Escalante, P. The genus Artemia Leach, 1819 (Crustacea: Branchiopoda). I. True and false taxonomical descriptions. Submission article platform. Lat. Am. J. Aquat. Res. 2011, 38, 501-506. [CrossRef]

23. Mwanja, M.; Rutaisire, J.; Ondhoro, C.; Ddungu, R.; Aruho, C. Current fish hatchery practices in Uganda: The potential for future investment. IJFAS 2015, 2, 224-232.

24. Nkambo, M.; Bugenyi, F.W.; Naluwayilo, J.; Nayiga, S. Artemia occurrence, salinity and ionic rates in saline crater lakes of western Uganda. IJE 2015, 5, 59-65. [CrossRef]

25. Nkambo, M.; (National Fisheries Resources Research Institute, Jinja, Uganda). Personal communication, 2016.

26. Coutteau, P. Micro-algae. In Manual on the Production and Use of Live Food for Aquaculture; Lavens, P., Sorgeloos, P., Eds.; Food and Agriculture Organization (FAO): Rome, Italy, 1996; ISBN 9251039348.

27. Dana, L.G.; Lenz, H.P. Effects of increasing salinity on an Artemia population from Mono Lake, California. Oecologia 1986, 68, 428-436. [CrossRef] [PubMed]

28. Van Stappen, G. Production, Harvest and Processing of Artemia from Natural Lakes. In Live Feeds in Marine Aquaculture; Støttrup, J.G., McEvoy, L.A., Eds.; Blackwell Publishing: Oxford, UK, 2003; pp. 122-144, ISBN 9780470995136.

29. Van Stappen, G.; Sui, L.; Xin, N.; Sorgeloos, P. Characterisation of high-altitude Artemia populations from the Qinghai-Tibet Plateau, PR China. Hydrobiologia 2003, 500, 179-192. [CrossRef]

30. Persoone, G.; Sorgeloos, P. General aspects of the ecology and biogeography of Artemia. In The Brine Shrimp Artemia Ecology, Culturing, Use in Aquaculture; Persoone, G., Sorgeloos, P., Roels, O., Jaspers, E., Eds.; Universal Press: Wetteren, Belgium, 1980; Volume 3, pp. 3-24.

31. Cole, G.A.; Brown, R.J. The chemistry of Artemia habitats. Ecology 1967, 48, 858-861. [CrossRef]

32. Bowen, S.T.; Durkin, J.P.; Sterling, G.; Clark, L.S. Artemia hemoglobins: Genetic variation in parthenogenetic and zygogenetic populations. Biol. Bull. 1978, 155, 273-287. [CrossRef]

33. Kappas, I.; Abatzopoulos, T.J.; Van Hoa, N.; Sorgeloos, P.; Beardmore, J.A. Genetic and reproductive differentiation of Artemia franciscana in a new environment. Mar. Biol. 2004, 146, 103-117. [CrossRef]

34. Clegg, J.S.; Jackson, S.A.; Hoa, N.V. Thermal resistance, developmental rate and heat shock proteins in Artemia franciscana, from San Francisco Bay and southern Vietnam. J. Exp. Mar. Biol. Ecol. 2000, 252, 85-90. [CrossRef]

35. Clegg, J.S.; Hoa, N.V.; Sorgeloos, P. Thermal tolerance and heat shock proteins in encysted embryos of Artemia from widely different thermal habitats. Hydrobiologia 2001, 466, 221-229. [CrossRef]

(C) 2018 by the authors. Licensee MDPI, Basel, Switzerland. This article is an open access article distributed under the terms and conditions of the Creative Commons Attribution (CC BY) license (http:/ / creativecommons.org/licenses/by/4.0/). 